\title{
PELATIHAN PENUSUNAN PERANGKAT PEMBELAJARAN BERBASIS KURIKULUM 2013 BAGI MGMP PPKn di KABUPATEN SANGGAU
}

\author{
Erna Octavia ${ }^{1}$, Rohani ${ }^{2}$, Hadi Rianto ${ }^{3}$, Fety Novianty ${ }^{4}$, \\ Dada Suhaida $^{5}$, Yuliananingsih ${ }^{6}$, Sulha $^{7}$ \\ 1, 2, 3, 4, 5, 6,7 Program Studi Pendidikan Pancasila dan Kewarganegaraan \\ Fakultas Ilmu Pendidikan dan Pengetahuan Sosial, IKIP PGRI Pontianak \\ Jalan Ampera No. 88 Pontianak \\ 1e_mail: putrikhanza96@yahoo.co.id
}

\begin{abstract}
Abstrak
Tidak bisa dipungkiri bahwa perubahan kurikulum selalu mengarah pada perbaikan sistem pendidikan. Perubahan tersebut dilakukan karena dianggap belum sesuai dengan harapan yang diinginkan sehingga perlu adanya revitalisasi kurikulum. Usaha tersebut mesti dilakukan demi menciptakan generasi masa depan berkarakter, yang memahami jati diri bangsanya dan menciptakan anak yang unggul, mampu bersaing di dunia internasional. Melalui pendekatan yang dilakukan berdasarkan kurikulum 2013 diharapkan siswa kita memiliki kompetensi sikap, ketrampilan, dan pengetahuan jauh lebih baik. Mereka akan lebih kreatif, inovatif, dan lebih produktif, sehingga nantinya mereka bisa sukses dalam menghadapi berbagai persoalan dan tantangan di zamannya, memasuki masa depan yang lebih baik. Adapun yang menjadi permasalahan dalam kegiatan yang dilaksanakan ini adalah sebagai berikut: (1) Masih rendahnya kemampuan guru dalam memahami pembuatan Perangkat Pembelajara PPKn sesuai dengan kurikulum 2013; (2) Masih rendahnya keterampilan guru dalam memahami pembuatan instrument penilaian sesuai dengan kurikulum 2013; (3) Belum memadainya keterampilan yang dimiliki oleh guru di daerah dalam mengembangkan media, model, strategi atau pendekatan pembelajaran.
\end{abstract}

Kata Kunci: Perangkat Pembelajaran Berbasis Kurikulum 2013, MGMP PPKn

\begin{abstract}
It is undeniable that curriculum changes always lead to improvements in the education system. The change is done because it is considered not in accordance with the desired expectations so that the need for curriculum revitalization. The effort must be done in order to create future generations of character, who understand the identity of the nation and create a superior child, able to compete in the international world. Through an approach based on the curriculum of 2013, we hope that our students will have better attitude, skills, and knowledge competencies. They will be more creative, innovative, and more productive, so that later they can succeed in dealing with the problems and challenges of their day, entering a better future. The problem in this activity is as follows: (1). The low ability of teachers to understand the making of PPKn's Toolkit in accordance with the 2013 curriculum; (2). The low level of teacher skills in understanding the making of assessment instruments in accordance with the 2013 curriculum; (3). Inadequate skills possessed by teachers in the region in developing media, models, strategies or learning approaches.
\end{abstract}

Keywords: Curriculum Based Learning 2013, MGMP PPKn 


\section{PENDAHULUAN}

Pendidikan nasional kita masih menghadapi berbagai macam persoalan. Persoalan itu memang tidak akan pernah selesai, karena substansi yang ditransformasikan selama proses pendidikan dan pembelajaran selalu berada di bawah tekanan kemajuan ilmu pengetahuan, teknologi, dan kemajuan masyarakat. Salah satu persoalan pendidikan kita yang masih menonjol saat ini adalah adanya kurikulum yang silih berganti dan terlalu membebani anak tanpa ada arah pengembangan yang betul-betul diimplementasikan sesuai dengan perubahan yang diinginkan pada kurikulum tersebut.

Tidak bisa dipungkiri bahwa perubahan kurikulum selalu mengarah pada perbaikan sistem pendidikan. Perubahan tersebut dilakukan karena dianggap belum sesuai dengan harapan yang diinginkan sehingga perlu adanya revitalisasi kurikulum. Usaha tersebut mesti dilakukan demi menciptakan generasi masa depan berkarakter, yang memahami jati diri bangsanya dan menciptakan anak yang unggul, mampu bersaing di dunia internasional.

Kurikulum sifatnya dinamis karena selalu berubah-ubah sesuai dengan perkembangan dan tantangan zaman. Semakin maju peradaban suatu bangsa, maka semakin berat pula tantangan yang dihadapinya. Persaingan ilmu pengetahuan semakin gencar dilakukan oleh dunia internasional, sehingga Indonesia juga dituntut untuk dapat bersaing secara global demi mengangkat martabat bangsa. Oleh karena itu, untuk menghadapi tantangan yang akan menimpa dunia pendidikan kita, ketegasan kurikulum dan implementasinya sangat dibutuhkan untuk membenahi kinerja pendidikan yang jauh tertinggal dengan negara-negara maju di dunia.

Penyelenggaraan pendidikan sebagaimana yang diamanatkan dalam Undang-undang Nomor 20 Tahun 2003 tentang Sistem Pendidikan Nasional diharapkan dapat mewujudkan proses berkembangnya kualitas pribadi peserta didik sebagai generasi penerus bangsa di masa depan, yang diyakini akan menjadi faktor determinan bagi tumbuh kembangnya bangsa dan negara Indonesia sepanjang jaman. 
Dari sekian banyak unsur sumber daya pendidikan, kurikulum merupakan salah satu unsur yang memberikan kontribusi yang signifikan untuk mewujudkan proses berkembangnya kualitas potensi peserta didik. Jadi tidak dapat disangkal lagi bahwa kurikulum yang dikembangkan dengan berbasis pada kompetensi sangat diperlukan sebagai instrumen untuk mengarahkan peserta didik menjadi: (1) manusia berkualitas yang mampu dan proaktif menjawab tantangan zaman yang selalu berubah; dan (2) manusia terdidik yang beriman dan bertakwa kepada Tuhan Yang Maha Esa, berakhlak mulia, sehat, berilmu, cakap, kreatif, man-diri; dan (3) warga negara yang demokratis dan bertanggung jawab. Pengembangan dan pelaksanaan kurikulum berbasis kompetensi merupakan salah satu strategi pembangunan pendidikan nasional sebagaimana yang diamanatkan dalam Undang-undang Nomor 20 Tahun 2003 tentang Sistem Pendidikan Nasional.

Pelaksanaan penyusunan kurikulum 2013 adalah bagian dari melanjutkan pengembangan Kurikulum Berbasis Kompetensi (KBK) yang telah dirintis pada tahun 2004 dengan mencakup kompetensi sikap, pengetahuan, dan keterampilan secara terpadu, sebagaimana amanat UU 20 tahun 2003 tentang Sistem Pendidikan Nasional pada penjelasan pasal 35, di mana kompetensi lulusan merupakan kualifikasi kemampuan lulusan yang mencakup sikap, pengetahuan, dan keterampilan sesuai dengan standar nasional yang telah disepakati. Paparan ini merupakan bagian dari uji publik Kurikulum 2013, yang diharapkan dapat menjaring pendapat dan masukan dari masyarakat.

Inti dari Kurikulum 2013, adalah ada pada upaya penyederhanaan, dan tematik-integratif. Kurikulum 2013 disiapkan untuk mencetak generasi yang siap di dalam menghadapi masa depan. Karena itu kurikulum disusun untuk mengantisipasi perkembangan masa depan. Titik beratnya, bertujuan untuk mendorong peserta didik atau siswa, mampu lebih baik dalam melakukan observasi, bertanya, bernalar, dan mengkomunikasikan (mempresentasikan), apa yang mereka peroleh atau mereka ketahui setelah menerima materi pembelajaran. Adapun obyek yang menjadi pembelajaran dalam penataan dan penyempurnaan kurikulum 2013 menekankan pada fenomena alam, sosial, seni, dan budaya. Melalui pendekatan yang dilakukan berdasarkan kurikulum 2013 diharapkan 
siswa kita memiliki kompetensi sikap, ketrampilan, dan pengetahuan jauh lebih baik. Mereka akan lebih kreatif, inovatif, dan lebih produktif, sehingga nantinya mereka bisa sukses dalam menghadapi berbagai persoalan dan tantangan di zamannya, memasuki masa depan yang lebih baik.

Ada beberapa dasar hukum yang digunakan dalam pengembangan kurikulum 2013 di Indonesia, antara lain :

1. Undang-undang Nomor 20 tahun 2003 tentang Sistem Pendidikan Nasional.

2. Undang-undang Nomor 32 tahun 2004 tentang Otonomi Pemerintah Provinsi dan Kabupaten/Kota.

3. Undang-undang Nomor 14 tahun 2005 tentang Guru dan Dosen.

4. Peraturan Pemerintah Nomor 19 tahun 2005 tentang Guru dan Dosen.

5. Peraturan Pemerintah Nomor 25 tahun 2000 tentang Kewenangan Pemerintah Provinsi dan Kabupaten/Kota sebagai Daerah Otonom.

6. Peraturan Pemerintah Nomor 74 tahun 2008 tentang Guru

7. Keputusan menteri Pendidikan Nasional Nomor 1 29a/U/2004 tentang Standar Pelayanan Minimal Bidang Pendidikan.

8. Permendikbud no. 23 Tahun 2013 tentang Perubahan atas Permendiknas no.

15 Tahun 2010 tentang Standar Pelayanan Minimal Pendidikan Dasar di Kabupaten/Kota

Target yang ingin dicapai adalah untuk meningkatkan pengetahuan, pemahaman dan keterampilan guru dalam menyusun Perangkat Pembelajaran Berbasis Kurikulum 2013. Sedangakan target khususnya yaitu:

1. Meningkatnya kemampuan, minat, inovasi, dan kreativitas para guru di Sekolah Menengah Pertama dengan menerapkan perangkat pembelajaran dan penilaian dengan format penilaian digital sesuai Kurikulum 2013, yang pada akhirnya peningkatan kompetensi dan kinerja sebagai guru profesional.

2. Meningkatnya kemampuan guru dalam mengelola pembelajaran yang terarah dan profesionalisme secara berkelanjutan.

3. Terbukanya wawasan guru tentang implementasi kurikulum 2013. 
4. Sekolah akan memiliki siswa yang siap untuk menhadapi masa depannya dalam membangun Bangsa Indonesia umumnya, membangun daerahnya pada khususnya.

5. Mendorong Sekolah Menengah Pertama menghasilkan lulusan yang berdaya saing tinggi dengan karakter yang memadai untuk melajutkan pendidikan yang lebih tinggi.

Kegiatan ini selain memberikan manfaat langsung kepada guru-guru juga akan berdampak positif kepada Dinas Pendidikan Kabupaten Sanggau, khususnya efisiensi anggaran rutin bagi peningkatan kualitas bidang pelatihan untuk tenaga guru. Melalui diklat ini, peserta akan dilatih untuk menyusun dan mengembangkan sendiri perangkat-perangkat pembelajaran yang diperlukannya dalam kegiatan pembelajaran. Perangkat pembelajaran yang akan dibuat meliputi silabus, RPP, buku siswa, lembar kerja siswa, dan pengelolaan nilai. Dengan menyusun dan mengembangkan sendiri perangkat pembelajaran yang diperlukan diharapkan proses pembelajaran dapat berjalan lebih baik dan lebih bersifat kontekstual sesuai dengan karakteristik lingkungan dan budaya di daerah masing-masing.

Adapun yang menjadi permasalahan dalam kegiatan yang dilaksanakan ini adalah sebagai berikut:

1. Masih rendahnya kemampuan guru dalam memahami pembuatan Perangkat Pembelajaran PPKn sesuai dengan kurikulum 2013.

2. Masih rendahnya keterampilan guru dalam memahami pembuatan instrumen penilaian sesuai dengan kurikulum 2013.

3. Belum memadainya keterampilan yang dimiliki oleh guru di daerah dalam mengembangkan media, model, strategi atau pendekatan pembelajaran.

\section{METODE}

Metode yang digunakan dalam pelaksanaan kegiatan ini sebagai berikut:

1. Metode ceramah, yaitu memperkenalkan konsep-konsep tentang Penyusunan Perangkat Pembelajaran PPKn Kurikulum 2013. 
2. Metode penugasan, yaitu menugaskan kepada guru-guru untuk menyusun perangkat pembelajaran mulai dari Silabus, RPP, dan Instrumen Penilaian.

Waktu kegiatan workshop/pelatihan Penyusunan Perangkat Pembelajaran Berbasis Kurikulum 2013 Bagi MGMP PPKn SMP di Kabupaten Sanggau akan dilaksanakan pada tanggal 11 November 2017. Pelaksanaan kegiatan ini diperuntuntukan bagi khalayak sasaran kegiatan pengabdian masyarakat ini adalah guru-guru SMP di Kabupaten Sanggau. Alasan pemilihan lokasi Ini di karenakan potensi pengembangan keterampilan guru dalam menyusun perangkat pembelajaran sesuai kurikulum 2013 dirasa sangat penting dalam hal upaya peningkatan kualifikasi tenaga pengajar khususnya di Kabupaten Sanggau.

Sebagai nara sumber dalam menyampaikan materi "penyusunan perangkat pembelajaran berbasis kurikulum 2013" adalah ibu Dr. Dada Suhaida, M.Pd, dan Tim pelaksana dari kegiatan ini adalah para tenaga pengajar (dosen) Program Studi Pendidikan Pancasila dan Kewarganegaraan IKIP PGRI Pontianak yang berjumlah 5 (lima) orang dengan susunan organisasi sebagai berikut.

\section{Ketua Pelaksana}
a. Nama dan Gelar Lengkap : Erna Octavia, M.Pd
b. Pangkat/Gol./NPP
: Penata Muda TK. I/III B/202 2011124
c. Jabatan Fungsional
: Asisten Ahli
d. Bidang Keahlian
: Pendidikan
e. Program Studi
: Pendidikan Pancasila dan Kewarganegaran

\section{Anggota Pelaksana :}
a. Fety Novianty, M.Pd
b. Rohani, M.Pd
c. Hadi Rianto, M.Pd
d. Yuliananingsih, $\mathrm{SH}, \mathrm{MH}$
e. Dra. H. Sulha, M.Si

\section{HASIL DAN PEMBAHASAN}

Pelaksanaan kegiatan Pelatihan Penyusunan Perangkat Pembelajaran Berbasis Kurikulum 2013 Bagi MGMP PPKn SMP di Kabupaten Sanggau 
dilaksanakan pada tanggal 11 November 2017 dari pukul 08.00 - 16.00 sudah terlaksana dengan baik tanpa ada hambatan yang berarti. Kegiatan workshop ini diawali dengan kata sambutan yang disampaikan oleh Kepala Dinas Pendidikan dan Kebudayaan Kabupaten Sanggau.

Dalam kata sambutan tersebut, kepala Dinas Pendidikan dan Kebudayaan Kabupaten sanggau memberikan penekanan kepada peserta pelatihan untuk serius dan konsentrasi dalam mengikuti pelatihan karena hasil positif dari pelatihan ini dapat diimplementasikan di tempat tugas masing-masing sehingga tujuan penyelenggaraan pendidikan khususnya mata pelajaran PPKn dalam membentuk karakter generasi muda dapat terlaksana.

Selanjutnya dilakukan penyampaian materi workshop oleh ibu DR. Dada Suhaida, M.Pd dilanjutkan dengan latihan menyusun perangkat pembelajaran sesuai kurikulum 2013. Pada kesempatan ini pemateri memberikan penekanan pada peserta tentang pentingnya sebuah perangkat pembelajaran dalam praktik mengajar di kelas. Khususnya pada mata pelajaran PPKn, perangkat pembelajaran merupakan pedoman utama dalam melaksanakan pembelajaran sehingga sisipansisipan nilai karakter utama yang diharapkan dapat dibentuk melalui kegiatan belajar mengajar dikelas dapat terwujud.

Menyusun perangkat pembelajaran dewasa ini sangatlah mudah. Dengan tersedianya informasi di internet memudahkan guru dalam membuat perangkat pembelajaran. Namun perlu diketahui apakah perangkat pembelajaran tersebut sesuai dengan kondisi serta budaya belajar siswa khususnya di kabupaten sanggau. Jawabannya tentu saja tidak sesuai karena cara belajar siswa berbedabeda berdasarkan letak geografisnya. Oleh karena itu Dr. Dada Suhaida memberikan penekanan khusus dalam penyampaian materi pelatihan ini dengan menyisipkan nilai-nilai kearifan lokal sebagai dasar pembentukan karakter siswa di sekolah.

Suasana kegiatan pelatihan Penyusunan Perangkat Pembelajaran Berbasis Kurikulum 2013 Bagi MGMP PPKn SMP di Kabupaten Sanggau tergambar dari beberapa foto dokumentasi yang diperoleh pada saat pelaksanaan kegiatan 
berlangsung. Adapun beberapa dokumentasi yang dapat ditampilkan adalah sebagai berikut:
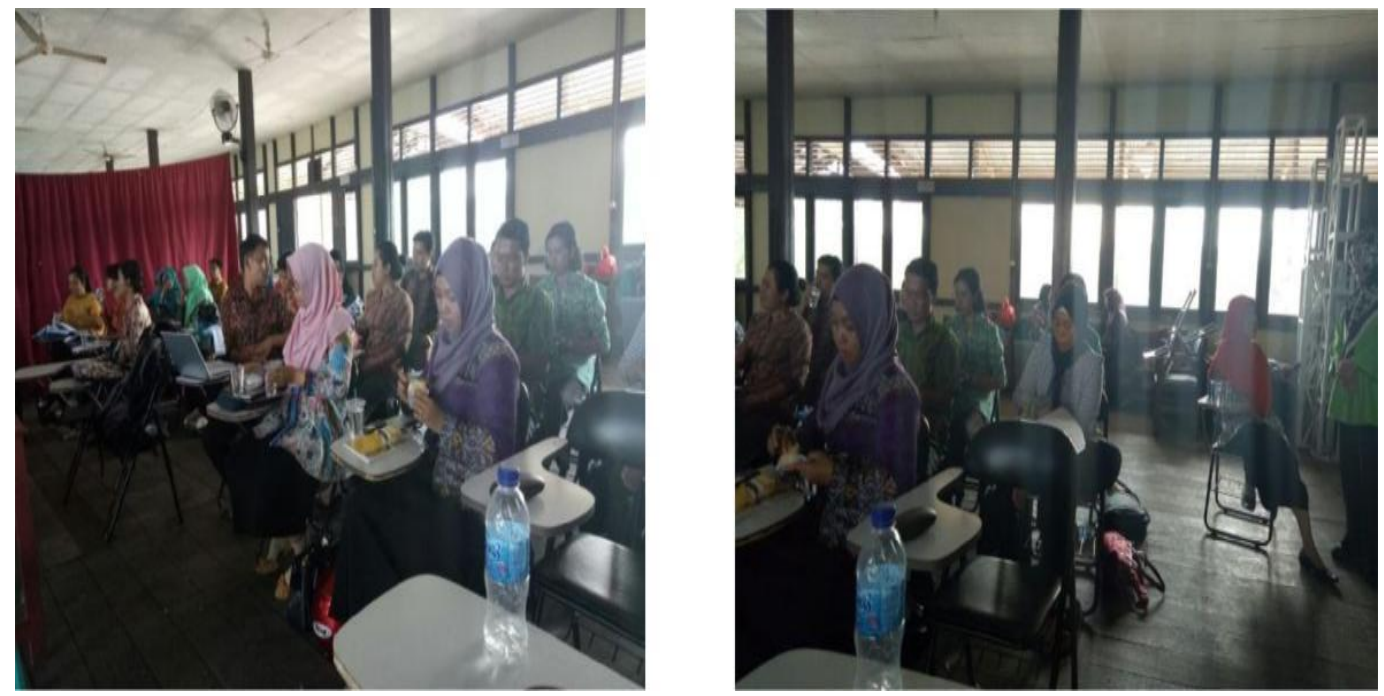

Gambar 1. Kondisi peserta pelatihan
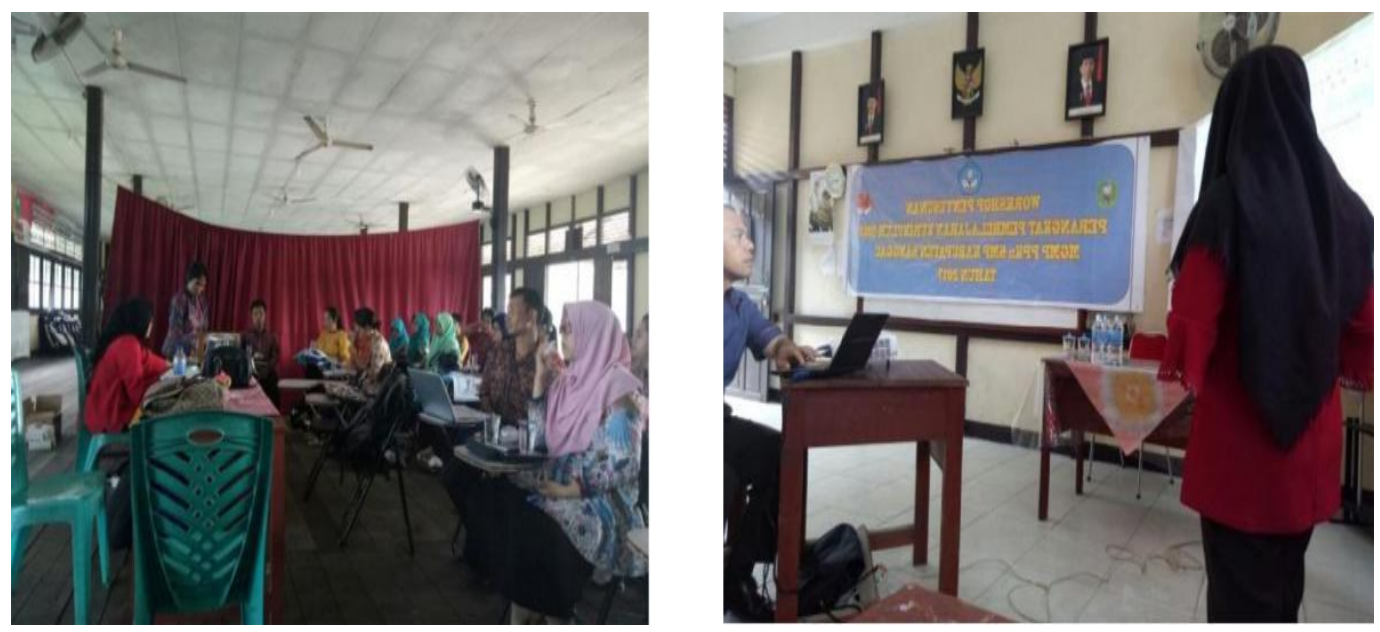

Gambar 2. Penyampaian materi Workshop 


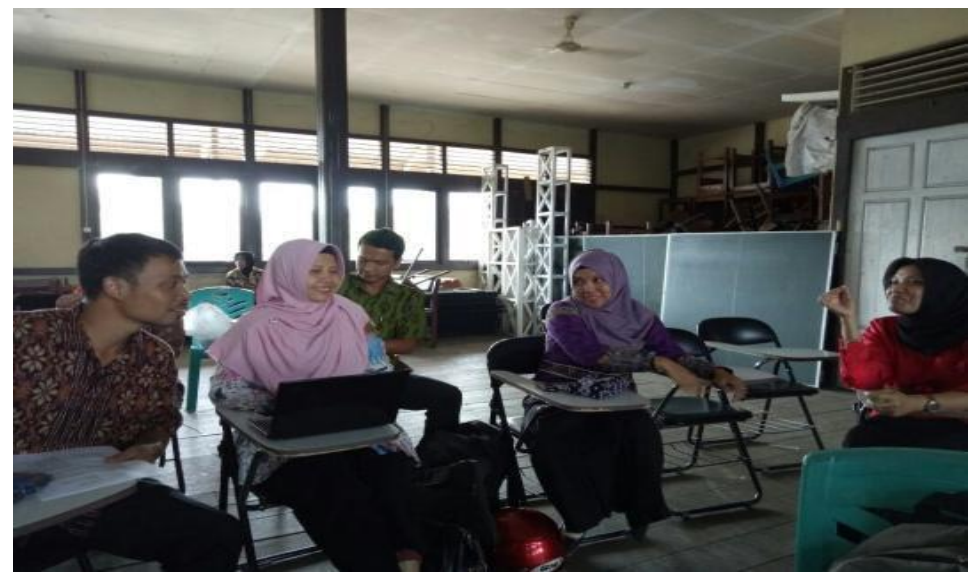

Gambar 3. Kondisi Diskusi peserta dalam diskusi kelompok kecil
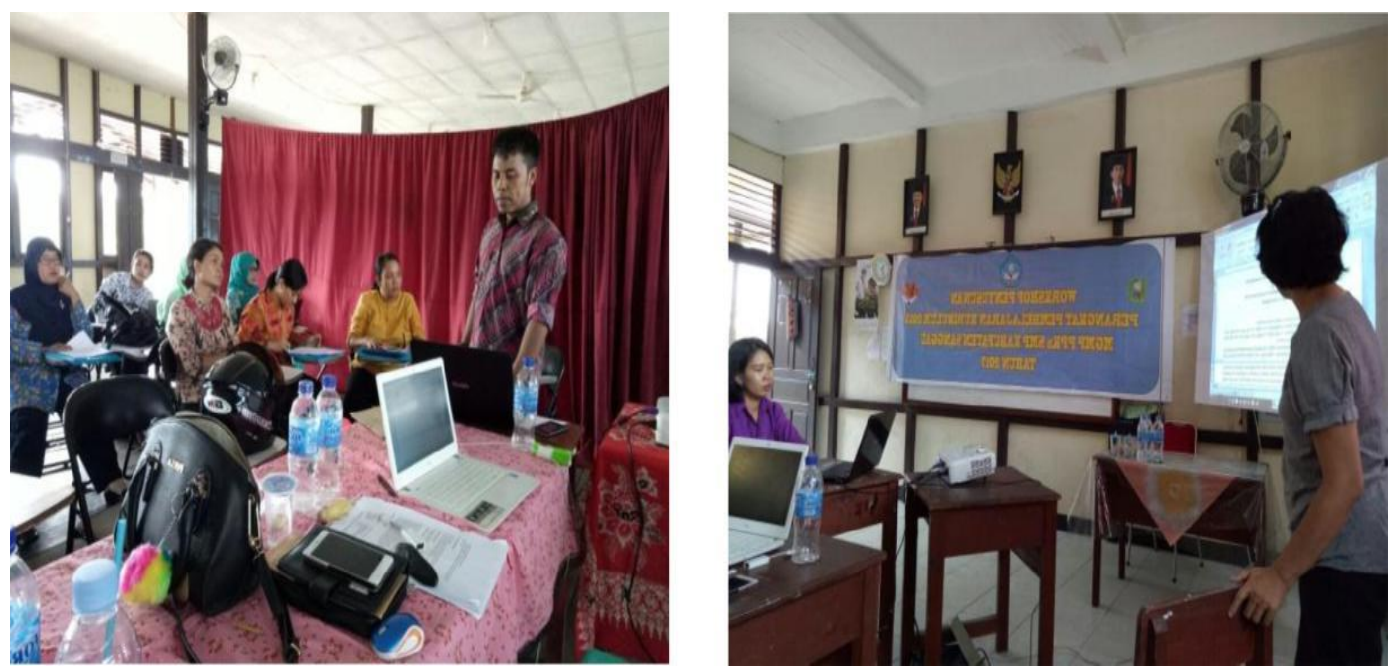

Gambar 4. Presentasi oleh peserta pelatihan

Capain target pelaksanaan kegiatan pengabdian kepada masyarakat ini secara umum adalah meningkatkan pengetahuan, pemahaman dan keterampilan guru dalam menyusun Perangkat Pembelajaran Berbasis Kurikulum 2013. Mengacu pada pelaksanaan kegiatan pada hari Sabtu tanggal 11 November 2017, maka hasil pelaksanaan kegiatan Workshop/Pelatihan Penyusunan Perangkat Pembelajaran Berbasis Kurikulum 2013 di jabarkan berikut ini:

1. Meningkatnya kemampuan, minat, inovasi, dan kreativitas para guru di Sekolah Menengah Pertama dengan membuat perangkat pembelajaran sesuai Kurikulum 2013, yang pada akhirnya peningkatan kompetensi dan kinerja sebagai guru profesional. 
2. Meningkatnya kemampuan guru dalam membuat instrument penilaian dengan format penilaian digital sesuai dengan kurikulum 2013, mengelola pembelajaran yang terarah dan profesionalisme secara berkelanjutan.

3. Terbukanya wawasan guru tentang implementasi kurikulum 2013, mengembangkan media, model, strategi atau pendekatan dalam proses pembelajaran.

Tindak lanjut dari pelaksanaan kegiatan Pelatihan Penyusunan Perangkat Pembelajaran Berbasis Kurikulum 2013 Bagi MGMP PPKn SMP di Kabupaten Sanggau adalah dengan memberikan follow up dan melaksanakan desiminasi kegiatan sehingga hasil pelatihan betul-betul bermanfaat bagi peserta yang mengikuti pelatihan dan bagi sejawat peserta.

\section{Tindak Lanjut}

Tindak lanjut ini dilakukan sebuah langkah yang dilakukan setelah kegiatan pelatihan dilaksanakan. Tindak lanjut penting untuk dilakukan agar informasi yang disampaikan kepada peserta pelatihan tidak cepat dilupakan begitu saja. Praktek tindak lanjut yang sederhana adalah dengan menanyakan kembali kepada peserta tentang pelatihan yang dilaksanakan sebelumnya. Tujuannya agar mendapatkan jawaban langsung dari peserta, selanjutnya tindak lanjut yang dilakukan adalah dengan penyusunan perangkat pembelajaran yang dibuat oleh setiap peserta dan dikumpulkan dalam bentuk soft file. Hal ini memudahkan penyelenggarakan untuk memberikan penilaian terhadap perangkat pembelajaran yang dibuat sesuai dengan indicator-indikator penyusunan rancangan pembelajaran yang telah disepakati dalam kegiatan pelatihan.

\section{KESIMPULAN}

Mengacu pada hasil kegiatan yang telah dilaksanakan, maka dapat disimpulkan bahwa:

1. Pelatihan Penyusunan Perangkat Pembelajaran Berbasis Kurikulum 2013 Bagi MGMP PPKn SMP di Kabupaten Sanggau dapat mengatasi rendahnya kemampuan guru dalam memahami pembuatan Perangkat Pembelajara PPKn sesuai dengan kurikulum 2013. 
2. Pelatihan Penyusunan Perangkat Pembelajaran Berbasis Kurikulum 2013 Bagi MGMP PPKn SMP di Kabupaten Sanggau dapat mengatasi rendahnya keterampilan guru dalam memahami pembuatan instrument penilaian sesuai dengan kurikulum 2013.

3. Pelatihan Penyusunan Perangkat Pembelajaran Berbasis Kurikulum 2013 Bagi MGMP PPKn SMP di Kabupaten Sanggau memberikan wacana baru bagi guru PPKn untuk dapat mengembangkan keterampilan yang dimiliki untuk mengembangkan media, model, strategi atau pendekatan pembelajaran.

\section{DAFTAR PUSTAKA}

Mulyasa, Pengembangan dan Impelemtasi Kurikulum 2013. (Bandung: PT Remaja Rosdakarya).

Sofan Amri, Pengembangan dan Model Pembelajaran dalam Kurikulum 2013. (Jakarta: Prestasi Pustaka, 2013).

Mulyoto, Strategi Pembelajaran di Era Kurikulm 2013, (Jakarta: Prestasi Pustaka Raya, 2013).

http://fatkoer.wordpress.com/2013/07/28/perbedaan-kurikulum-2013-dan-ktsp 